\title{
MUSIC BEYOND AIRPORTS APPRAISING AMBIENT MUSIC
}

Edited by Monty Adkins \& Simon Cummings 
Published by University of Huddersfield Press

University of Huddersfield Press

The University of Huddersfield

Queensgate

Huddersfield HD1 3DH

Email enquiries university.press@hud.ac.uk

First published 2019

This work is licensed under a Creative Commons Attribution 4.0

International License

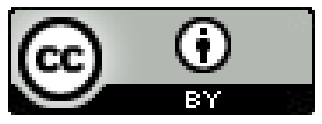

Images (C) as attributed

Every effort has been made to locate copyright holders of materials included and to obtain permission for their publication.

The publisher is not responsible for the continued existence and accuracy of websites referenced in the text.

A CIP catalogue record for this book is available from the British Library.

ISBN: 978-1-86218-161-8

Designed by Dawn Cockcroft 
CONTENTS

INTRODUCTION

CHAPTER 1

David Toop

How Much World Do You Want? Ambient Listening

And Its Questions

CHAPTER 2

21

Ambrose Field

Space In The Ambience: Is Ambient Music

Socially Relevant?

CHAPTER 3

51

Ulf Holbrook

A Question Of Background: Sites Of Listening

CHAPTER 4

Richard Talbot

Three Manifestations Of Spatiality In Ambient Music

\section{CHAPTER 5}

83

Simon Cummings

The Steady State Theory: Recalibrating The

Quiddity Of Ambient Music 
Monty Adkins

Fragility, Noise, And Atmosphere In Ambient Music

\section{CHAPTER 7}

\section{Lisa Colton}

Channelling The Ecstasy Of Hildegard Von Bingen:

"O Euchari" Remixed

\section{CHAPTER 8}

Justin Morey

Ambient House: "Little Fluffy Clouds" And

The Sampler As Time Machine

CHAPTER 9

Axel Berndt

Adaptive Game Scoring With Ambient Music 